\title{
Coastal vulnerabilities under the deliberation of stakeholders: The case of two French sandy beaches
}

\author{
Marc Poumadère a, *, Raquel Bertoldo a, b , Deborah Idier c ${ }^{\text {, Cyril Mallet }}{ }^{\text {c }}$, Carlos Oliveros ${ }^{\text {d, }}$ \\ Marc Robin ${ }^{\mathrm{e}}$ \\ a Institut Symlog, 262 rue Saint Jacques 75005 Paris, France \\ ${ }^{\mathrm{b}}$ Instituto Universitário de Lisboa (ISCTE-IUL), Cis-IUL, Av. das Forças Armadas, 1649-026 Lisboa, Portugal \\ ${ }^{\mathrm{c}}$ Bureau de Recherches Géologiques et Minières, Direction DRP, 3 Avenue C. Guillemin, 45060 Orléans Cedex 2, France \\ d Bureau de Recherches Géologiques et Minières, Service RNSC, 3 Avenue C. Guillemin, 45060 Orléans Cedex 2, France \\ e 8 Littoral - Environnement - Télédétection - Géomatique, UMR CNRS 6554, Pôle Mer et Littoral, Université de Nantes, BP 8122,44312 Nantes, France
}

\section{A R T I C L E I N F O}

\section{Article history:}

Received 7 May 2014

Received in revised form

24 September 2014

Accepted 21 December 2014

Available online 13 January 2015

\section{Keywords:}

Sandy beach

Stakeholders

France

Climate change adaptation

Noirmoutier

Truc Vert

\begin{abstract}
A B S T R A C T
Coastal environment systems are always exposed to natural phenomena such as erosion and submersion, and climate change is likely to increase these phenomena and their related vulnerability. The decision whether or not to protect the coast from an extreme weather event is not only based on technical data, but must also take into account its social acceptability. The involvement of stakeholders thus appears as a risk governance option. By using a scenario (both physical and socio-economic) and workshop methodology, we compare the deliberations and recommendations made by stakeholders facing a storm scenario in two different locations on the French Atlantic coast in the future (2030): Truc Vert and La Tresson-Noirmoutier. Group deliberations were content-analyzed in order to reveal the main directions taken by the debate. A conservative 'wait and see' option was favored in the less occupied region (Truc Vert), and a more protective option was preferred in the polderised and more intensively inhabited region of La Tresson-Noirmoutier.
\end{abstract}

() 2014 Elsevier Ltd. All rights reserved.

\section{Introduction}

In the last twenty years, it has become evident that climate change debate and policy have been negatively impacted by the complexity and the lack of scientific certainties associated with the phenomenon (Uzelgun and Castro, 2014). The two major objectives of such policy, to decrease energy consumption and decrease the emission of greenhouse gasses (GHG), have not been met (Burck et al., 2013). Moreover, recent research indicates that both energy consumption and GHG emissions continue to increase, although at a reduced rate (Olivier et al., 2013). This situation indicates that we are currently at a crossroads in which policy-makers will have to make challenging choices about how to successfully move forward in order to manage potentially dangerous environmental effects induced by climate change (CLIMATE-ADAPT, 2014; Poumadère

\footnotetext{
* Corresponding author.

E-mail addresses: poumadere@wanadoo.fr (M. Poumadère), raquel_bertoldo@ iscte.pt (R. Bertoldo), D.Idier@brgm.fr (D. Idier), c.mallet@brgm.fr (C. Mallet), c. oliveros@brgm.fr (C. Oliveros), marc.Robin@univ-nantes.fr (M. Robin).
}

et al., 2011).

Coastal environment systems are always exposed to natural phenomena such as erosion and submersion, and climate change is likely to increase these phenomena and their related vulnerability. Considering that $40 \%$ of the world's population lives within $100 \mathrm{~km}$ distance to the coast (UNEP, 2007), the increase in coastal vulnerability is an issue of great concern for politicians and stakeholders around the world (Adger et al., 2005). Coastal resilience-building and adaptation means that communities must face the alternatives: either to protect their territory or 'let it go'.

Such complex decision-making relies upon a large set of factors, typically ranging from scientific assessments to stakeholders risk perceptions. Clearly, decision-making includes more variables than the available scientific data - for example, a technical advice needs to be well received by the public, affordable, or cost effective (Poumadère et al., 2011). In this situation, what is the weight of each factor? How do various levels of reasoning and affect come into play? To tackle these questions at a pragmatic level, we present a scenario and workshop methodology associating scientific resources and local stakeholders involvement. Both physical and 
socio-economic scenarios were developed to create a situation where stakeholders were required to deliberate and recommend actions in face of a simulated storm that would have hit two different locations on the French Atlantic coast in 2030.

\subsection{Scientific and social knowledge}

In order to favor adapted courses of action, decision makers must resort to different types of information. Besides technical and scientific inputs, stakeholders also make use of a set of informally shared information that circulates among different social groups and in institutions in society. This hot, immediate, and informally shared knowledge correspond to what Moscovici (2008) denominates social representations. The social representations framework is interested in studying meaning making efforts that are instrumental to support interindividual communication and behavior (Moscovici, 2008). Contrary to the 'deficit model' where "objective scientists are juxtaposed to irrational lay people in many theories of the human response to risk" (Joffe, 2003, p. 58, italics added), social representations regard collective meanings construction not as a distortion of something objective, but as something completely new. Environmental risks are also submitted to this social construction process through the selection of those aspects that are congruent with pre-existing ideas and cultural understandings, what changes them and the same time that renders them familiar (Castro, 2002; Gruev-Vintila and Rouquette, 2007; Joffe, 2003). This type of process has been observed in relation to a variety of environmental risks such as floods (Baggio and Rouquette, 2006) and earthquakes (Gruev-Vintila and Rouquette, 2007).

The type of lay knowledge that constitutes social representations is capable of integrating seemingly paradoxical information (Castro and Lima, 2001) by following a logic that is different form the non-contradiction logic present in the scientific rationale: a logic that "does not bind itself down to avoiding contradiction. It obeys the laws of participation first and foremost" (Lévi-Bruhl, 1910/ 1985, p. 78, italics added). This type of representational work is especially observable in the production of discursive material, which we will analyze from the content produced in the workshops with local stakeholders.

\subsection{Climate change: decision making under uncertainty}

Risks associated with climate change, on the other hand, are more subjected to debate. Even the mere existence of the phenomena was contested until very recently due to its lack of 'objectivity' (Knorr-Cetina, 1997). However, the dangers of future climate change depend on how our society is willing to respond to the phenomenon in the short term: the more we ignore our role in climate change, the closer the phenomenon is to reach a turning point where consequences are much worse (IPCC, 2014; Meinshausen et al., 2009).

Irrespective of how successful are climate change mitigation measures, adaptation actions for more resilient coastal environment account for decreased vulnerability, and are already being implemented in Europe (EEA, 2014). This approach understands that "it is the capacity to respond to change, rather than the ability to avoid or be protected from change which is viewed as a key to system resilience" (Lamson, 2008, p. 272, italics added). Adaptation and resilience-building is especially important if we consider coastline environments, which are vulnerable to the many hazards associated with climate change (Adger et al., 2005). Resiliencebuilding measures often include a series of options ranging from artificial 'hard' shoreline interventions to natural actions that include biodiversity conservation and community involvement.
Despite all the debate around climate change adaptation and mitigation, policymakers take actions today. In order to make a choice that makes sense scientifically, politically and socially, they resource not only to scientific recommendations, but to a large extent to culturally shared ideas about the environment and risks (Adger et al., 2005; Delicado et al., 2012; Poumadère et al., 2008). Let us now present a method to explore how more extreme and yet abstract decisions could be taken by stakeholders and policymakers under the pressure of an emergency situation.

\subsection{Extreme scenarios}

Policy makers and stakeholders are used to decide under a certain amount of pressure, but they are often not prepared for extreme climate scenarios, which are low in probability but have high impacts (Tol et al., 2006). The responses to extreme climate scenarios are highly dependent upon local frames: the local historical background, natural resources, and of course, their perceived capacity to react. This is what motivated the Atlantis project to compare the reactions of stakeholders' from three different countries (the Netherland, England and France) to a collapse of the West Atlantic Ice Sheet (WAIS) leading, in a 'worstcase scenario', to 5-6 m sea level rise in the year 2100 (Tol et al., 2006). This project engaged key stakeholders in the (1) elaboration of a future social scenario and in the (2) debate and decision about what should be decided at different time frames in the future (2030 or 2050). Decisions taken by stakeholder groups suggest that the city of London will invest massive resources to protect the Thames estuary - an area of growing urbanization. In the Rhine delta in the Netherlands on the other hand, a retreat plan is foreseen, even for the industrialized areas. In France, deliberations suggest that a 'wait and see' position is likely in the low density are of the Rhône delta (Camargue) when the WAIS collapse is announced as likely in 2030. It is only after a rise of an average of $1 \mathrm{~m}$ in 2050 that participants decide to organize a retreat, leaving the delta to its natural hydrological functions (Poumadère et al., 2008). By engaging local key stakeholders, this project was able to qualitatively analyze an extreme scenario and to "understand the societal response to such an extreme change" (Tol et al., 2006).

The study presented in this article also applies a worst-case scenario methodology (Poumadère et al., 2008; Tol et al., 2006) to analyze the deliberations and the decisions made by local stakeholders in response to an extreme event: a storm of unusual proportions. These stakeholders are engaged in different portions of the French coast, with different types of coastal vulnerabilities to marine submersion: Truc Vert (a beach devoid of human permanent dwellings, located in the Aquitaine region) and La Tresson (on the inhabited and polderised peninsula of Noirmoutier, in the Vendée region) (Fig. 1). This choice was based on differences in terms of hydrodynamic and socio-economical characteristics: these two sites have different patterns of morphological, physical, space occupation and utilization characteristics (Idier et al., 2013).

The proposed event, a storm happening in 2030, was described in both physical and socio-economic terms. The task given to the stakeholders group consisted in advising policymakers about the course of actions they should favor on the basis of the situation presented in the scenarios (see Poumadère et al., 2008; Tol et al., 2006). As described above, this methodology permits the simulation of a real situation where participants (local stakeholders) are led to debate and propose a recommendation about the actions they consider being best suited for the situation. Besides the advantages of the exercise for local leaders, this methodology allows the analysis of ( 1 ) the courses of action considered by the group as a whole and resulting in the workshop sessions' resolutions, and (2) the group deliberations about the scenario proposed during the 
workshop sessions.

It was expected that, based on their different local characteristics, stakeholders would favor, in the different sites, different courses of action to the risk of marine submersion in face of an unusually strong, yet plausible, storm (Idier et al., 2013). In contrast with Tol et al. (2006), the scenarios used in the workshops here described are not 'worst-case' scenarios for two reasons. The first reason is that the storm event presented was built using real data of maximum levels reached simultaneously by wind, wave and tide, and assuming values that are slightly larger than those observed in real events in the past. Put together, these variables create a storm that, by its nature and impact, can be characterized as a critical event. The second difference between the scenario used in this study a worst-case one, is its time frame. By choosing 2030 instead of 2100, stakeholders find themselves within a time frame more compatible with their actual life perspective, which would lead them to a greater involvement with the proposed situation.

The engagement of stakeholders in discussing real hydrodynamic scenarios can raise the precision of hydrodynamic models through the integration of these models in their intentions of protecting (or laissez-faire) the area (Idier et al., 2013). These methodologies provide stakeholders with a good opportunity to more concretely reflect about the future - over and above the climate issues - and about the possible future consequences of presently taking one course of action or another. Paradoxically, preventing a disaster requires us to be convinced that it will happen (Dupuy, 2004).

Summing up, we will attempt to address these questions:

1. How do the physical and socio-economical characteristics of the Truc Vert and La Tresson (Noirmoutier) beaches influence:

a. What is discussed by local stakeholders in each workshop, i.e., what content is brought to the debate? In order to respond to this question, the debate in each workshop was content analyzed with the support of the ALCESTE software.

b. The course of actions privileged by local stakeholders? In the end of each workshop, participants were required to provide a set of recommendations to policymakers.

2. What can coastal risk management learn from these scenariobased workshops?

\section{Method}

In order to prepare convincing and useful workshops, a series of other preparatory activities were necessary, which we will describe below in a chronological order: individual interviews, the scenario construction, followed by the workshop activity itself and then finally, the analysis of the discursive material content.

\subsection{Individual interviews}

Considering the importance of recruiting stakeholders who are active and engaged in the region, this phase started with the identification of key stakeholders that were public service representatives, elected bodies, associations, managers of camping sites, farmers and fishermen, among others. An initial list of stakeholders was contacted and interviewed. In some cases, interviewees would also suggest other stakeholders that they considered to be important actors in the region. We continued to explore this network until we had contacted almost everyone they had suggested. The group of stakeholders initially interviewed consisted of 22 participants in Truc Vert and 17 in la Tresson-Noirmoutier.

During the interviews, stakeholders were asked to imagine the consequences that a marine submersion caused by a heavy storm in 2030 would have on their community. From this initial point, interviewees were questioned about how they imagined their community would be like in the future: how the demographics, the economy, and other major local works would evolve until 2030? They were also inquired about the local sectors they considered as those that would suffer the most when affected by an unusually heavy storm, and what response they expected from their local government and from the local population.

The content of these interviews was analyzed so as to grasp the main predictions stakeholders made about the future of their communities. The picture formed by those social, economic and political aspects that were commonly mentioned by different stakeholders composed the socioeconomic scenario we have used in the workshop session. This scenario grouped the most important characteristics and strategies of risk management of each study site (Table 1). For example, the almost desert sandy beach of Truc Vert was mainly thought as a forest with no real interest in being protected from submersion. In contrast, the polderised site of La Tresson-Noirmoutier, where land was conquered from the sea by the community generation after generation, retreat was not seen as an option. Regarding this last site and the fact that the local community lives under the sea level, contributes to what an interviewed stakeholder called a "local culture of flood risk", given that the odds of a marine submersion are real and which they are

Table 1

Synthesis of the issues raised by stakeholders during the individual interviews.

\begin{tabular}{|c|c|c|}
\hline & Truc Vert & Noirmoutier \\
\hline Characterization & $\begin{array}{l}\text { - Erosion problem; } \\
\text { - After the dune, there are } \\
\text { only light structures, such as } \\
\text { parking lots and a camping } \\
\text { site. }\end{array}$ & $\begin{array}{l}\text { - Polder zone for agricultural } \\
\text { expansion; } \\
\text { - Local risk culture: “Those } \\
\text { who live here for a long time } \\
\text { have incorporated the inun- } \\
\text { dation risk. However, those } \\
\text { whose properties are second } \\
\text { residence fear the risk and } \\
\text { leave". }\end{array}$ \\
\hline $\begin{array}{l}\text { Possible } \\
\text { solutions }\end{array}$ & $\begin{array}{l}\text { - Strategic retreat: it would } \\
\text { be a natural evolution as it } \\
\text { has always been the case. } \\
\text { "We should let the nature } \\
\text { take its course". } \\
\text { - Weak cost-benefit report: } \\
\text { "There would be nothing to } \\
\text { protect in Truc Vert" }\end{array}$ & $\begin{array}{l}\text { - Here the retreat is not an } \\
\text { option: "Here we are for the } \\
\text { fight against the sea more } \\
\text { than the retreat. We must go } \\
\text { on to the limits of what can } \\
\text { be done, what means build- } \\
\text { ing defenses" } \\
\text { - Hard or light defenses? Give } \\
\text { room for nature in order to } \\
\text { reinforce natural defenses or } \\
\text { reinforcing hard defenses, } \\
\text { such as dikes? }\end{array}$ \\
\hline
\end{tabular}

"We need both: hard protections aligned to light ones, letting nature establish itself" "We ask ourselves what to do with the dunes? Should we continue with the protections and end up like the walled-city of Carcassone? Or should we privilege the protection of some more vulnerable areas?" - Real estate crisis: the simple presence of hard defenses makes the risk visible, which reduces the real estate values. "Following the attention given to coastal risks, we observe the emergence of a real estate crisis". After the Xynthia storm, some "black zones' (submergible zones) have been established, what could increase the problem 


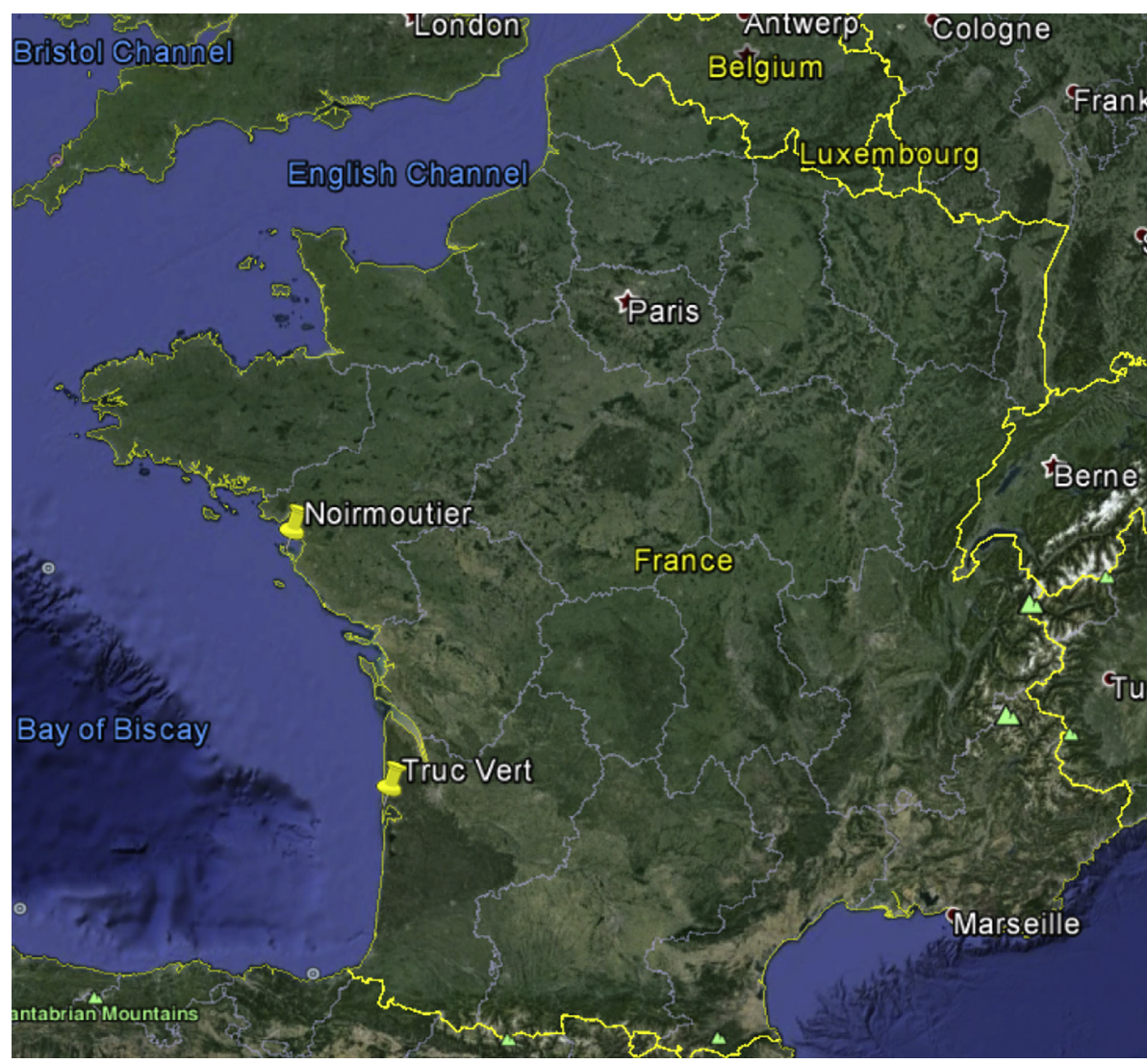

Fig. 1. Truc Vert and La Tresson-Noirmoutier locations on the French Atlantic coast.

prepared to fight against.

All the interviewed participants were also invited to take part in a workshop that would gather the region's main stakeholders regarding coastal management.

The individual interviews were a very important element to assure the success of the workshop sessions. They were important to:

- Construct of a socioeconomic scenario for each site in 2030;

- Personally involve the participating stakeholder within the research project, raising the engagement with the project as well as the likelihood that s/he would take part on the workshop. This was a way to deal with a well-known and repeatedly experienced limit of risk governance: the practical difficulty to engage stakeholders into deliberative activities (Renn, 2008);

- Facilitate the understanding of the methodology and prepare future participation of stakeholders in the workshop session, which requires handling rather complex data, together with the specific frame of the scenario. Evidence of the positive impact of this preparation became apparent when an interviewed participant could not come and sent a representative. The latter was visibly lagging behind the group's activity and had more difficulties to discuss and develop strategies with other stakeholders.

- Pre-elaborate the content brought to group discussion through a previous reflection on the matter with the interviewer. In this sense, the workshop was more a moment for the exchange of ideas than a moment where stakeholders would forge an initial opinion on the matter.

\subsection{Scenario construction}

For each site, two different scenarios were built: physical and a socioeconomic. The procedure for preparing the socioeconomic scenario was described above in the interview section. The preparation of the physical scenario is described below.

The physical scenario contains aspects such as beach dynamics (topo-bathymetric evolution, hydrodynamic forcing conditions) at a decadal as well as at a short time scale (i.e. few days). Based on the combination of present dynamics observed in each of the study sites, and of the IPCC (2007) predictions for climate change in the middle-future, project partners presented to the stakeholders present in the workshop a fictive, yet plausible, storm event taking place in 2030. At the Truc Vert beach, the extreme event described was a storm with similar characteristics, but slightly stronger than the real Xynthia storm ${ }^{1}$ : the sea crossed over the natural barrier of the beach dune and damaged the parking lot, together with the wooden cabins installed at the sea front. Furthermore there was dune erosion at beach, and sand transport inland, perturbing the car traffic (see Idier et al., 2013). At la Tresson beach (Noirmoutier), the storm was characterized by cutting the island in half: abnormally high waves crossed over the dunes and opened a passage to the other side of the island (see Fig. 1).

The socioeconomic and the physical scenarios were presented together in each study site, the socioeconomic scenario setting the context for the physical one. They were combined to provide

\footnotetext{
${ }^{1}$ Xynthia was a violent European windstorm that crossed Western Europe between 27 February and 1 March 2010. It happened during the individual interview phase of this project.
} 


\section{L'océan a brisé le cordon des dunes}

La tempête du 26 mars 2030 restera longtemps gravée dans les esprits des habitants du Bassin d'Arcachon. De mémoire d'Aquitain, jamais l'océan n'avait ainsi franchi les dunes du Truc Vert. Un spectacle qui désole et interpelle à la fois mais surtout nourrit un débat passionné entre riverains et experts venus nombreux constater les dégâts. Une seule question : et maintenant, que faire?

\begin{abstract}
a nouvelle de la " catastrophe " attire depuis samedi, riverains, élus et agents de I'ONF et du Conservatoire du littoral au pied de la dune qui prend peu à peu des airs de forum à cie ouvert. Sujet du jour : l'avenir proche de la plage et les actions à mener d'urgence.

Devant l'ampleur de la tâche et son caractère inédit, les avis sont pou l'instant partagés. Le maire du Cap-Ferret, Simon Bernard, envisage de s'atteler dès maintenan à des travaux lourds de terrassement et de reconstruction de la dune. «Il nest pas envisageable de laisser ce trou béant qui expose un peu plus encore la forêt à larrière, voire le Cap-Ferret. À la prochaine tempête l'eau repassera par là, aggravant un peu plus la situation, sans compter cet aspect dégrade laissant la dune démunie face au vent qui emporte le sable à l'intérieur des terres. On mettra le nombre d'engins qu'il faudra mais le sa ble, on le ramènera où il était. *
\end{abstract}

\section{Des solutions a inventer}

La question financière ne l'arrête pas. " Plus on attend plus le coût des travaux augmentera. Encore quelques tempétes comme celle-là

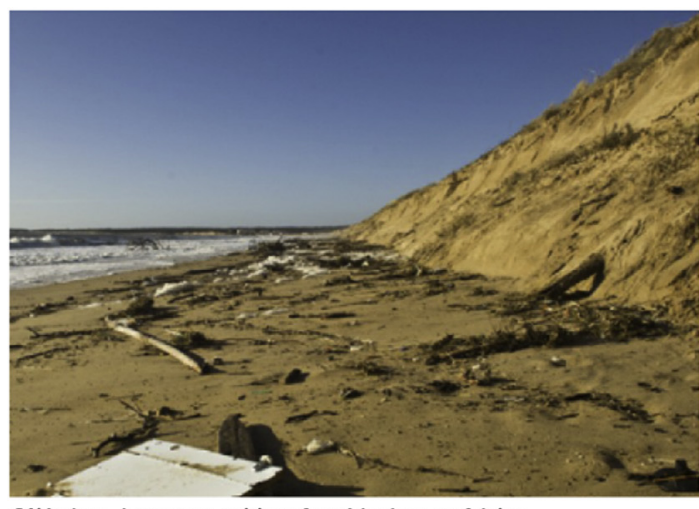

cóté plage, les vagues ont transformé la dune en falaise.

- et je ne le souhaite pas - et c'est tion de la dune est un travail lent, toute la dune du Truc Vert quil auquel l'homme peut concourir. I faudra refaire". peut favoriser, accélérer mais non De son côté, Nicole Lombardi, pas remplacer le travail des magarde du littoral depuis quinze ans rées, des vents, de la houle. " dans le secteur, ne conteste pas Une chose est súre, cet événement l'urgence mais craint qu'essayer exceptionnel demandera certained'aller trop vite par rapport à la na- ment de recourir à de nouveaux ture ne soit la source de nouveaux modes d'action, à imaginer, ou problèmes à venir. « La construc- d'adapter les expériences menées

Indiscrétion. Un appel d'offres va être lancé pour la plage de l'Horizon : les travaux, objet du present marché, concernent un transfert de sable, reconstitution de dunes et la mise en place de protection par pieux bois et ganivelles sur les ouvrages maritimes. dans des zones littorales comparables et déjà confrontées au même problème. Ces expérimentations d'aujourd'hui, alliées à l'étude poussée des catastrophes comme celle que nous venons de connaitre forgent la mémoire de demain.

\section{Accepter l'aléa}

«Les dunes sont aussi pittoresques qu'utiles. Elles sont donc l'objet d'un grand nombre de mesures de protection. Mais peut-être devrions-nous accepter les rythmes de la mer et du vent, quitte à les laisser se répandre dans les terrains humides? Renoncer à dompter ces gigantesques masses de sable et accepter leur nature mobile? » Ce à quoi Simon Bernard répond que « la Route du Truc-Vert ne l'est pas, elle, mobile. "

On s'aperçoit que ces espaces que on pourrait penser sauvages par méconnaissance, abandonnés, sont en réalité l'objet d'une surveillance scrupuleuse et se trouvent au coeur d'énormes enjeux.

Le propriétaire du camping tout proche préfère ironiser pour éva-

cuer un peu le stress des derniers dalos qu'il me faudra. Quoi qu'un camping en bord de lagune... jours : « à ce rythme-là, c'est des péMireille Dumont

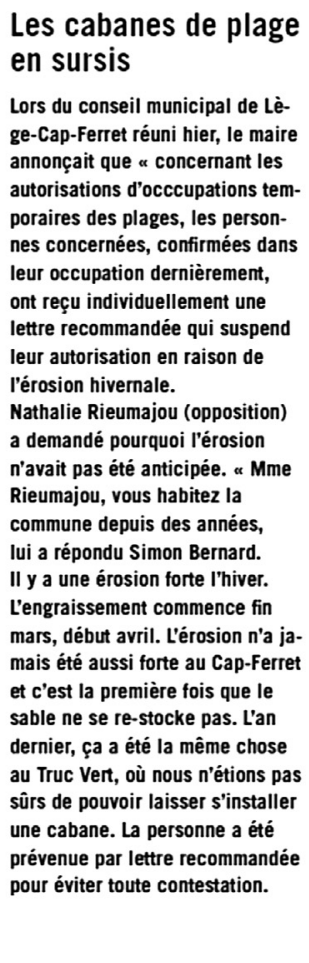

Les cabanes de plage

Lors du conseil municipal de Lèap-Ferret réuni hier, le maire utorisations d'occcupations temdes leur occupation dernièrement, nas été anticipée. « M commune depuis des années, lui a répondu Simon Bernard. Il y a une érosion forte l'hiver. (in mais été aussi forte au Cap-Ferret et c'est la première fois que le re-stocke pas. L'an au Truc Vert, où nous n'étions pas sûrs de pouvoir laisser s'installer cabane. La personne a été prévenue par lettre recommandé

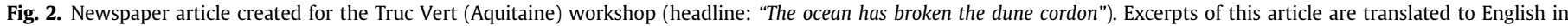
annex.

content for a journalistic article dated 2030. This article was presented to participants as an initial input for their group deliberation (Figs. 2 and 3).

\subsection{Workshop sessions}

\subsubsection{Participants}

Stakeholders, who had been previously interviewed, were then invited to participate in the workshop. Stakeholders from the Truc Vert site convened at the $\mathrm{BRGM}^{2}$ facilities in Bordeaux. The five stakeholders that attended the meeting represented national, regional and local scales of the governance and an environmental association. Some 11 stakeholders had initially confirmed their presence, but by a meteorological coincidence, a real storm had been forecasted to hit the coast during the day of the workshop. This was the reason why only five were able to come to the meeting. For instance, the mayor of the commune near Truc Vert had to stay on location to coordinate protective action.

Stakeholders from the La Tresson site convened at the

\footnotetext{
${ }^{2}$ BRGM (Bureau de Recherches Géologiques et Minières) is the French geological survey. It coordinated the overall study and scientists from this institution developed the physical scenario. http://www.brgm.eu/content/brgm-french-geological-
} survey.
Herbaudière port, at the Noimoutier Island. The 11 stakeholders that attended the meeting also represented different scales of regional and local governance, the National Forest Agency, among other associations and a local businesses (a camping pitch).

\subsubsection{Workshop procedure}

Sessions were prepared to last a maximum of $4 \mathrm{~h}$ during starting at $13 \mathrm{~h} 30$, with a coffee break in the middle. Both sessions took place in the first semester of 2010 .

Workshops began with a presentation of models predicting the evolution of the coast until 2030 (see Idier et al., 2013): topobathymetric evolution and hydrodynamic forcing conditions. In a second moment, and based on these real results, a storm that supposedly had taken place in 2030 was presented. It was clear from the presentation that the combination of the factors forming the depicted storm was unprecedented, yet plausible, and was accepted as realistic by participants in a 2030 horizon.

After the oral exposition of the storm event, a fictitious newspaper article, dated 2030, was distributed (Figs. 2 and 3). This article was edited by a professional journalist who integrated the socioeconomic and the physical scenarios with some of the interviewee's quotations in order to deliver a realistic everyday life account of a storm and its consequences. Furthermore, in the case of La Tresson-Noirmoutier, a modified satellite picture showed the Island cut in half after the 2030 storm. This support material 


\section{Noirmoutier séparée par la tempête}

\section{La tempête Victor a durement frappé sur l'île de Noirmoutier, séparée en deux pendant quelques heures quand l'océan a franchi la dune de la Tresson. Premières impressions sur place.}
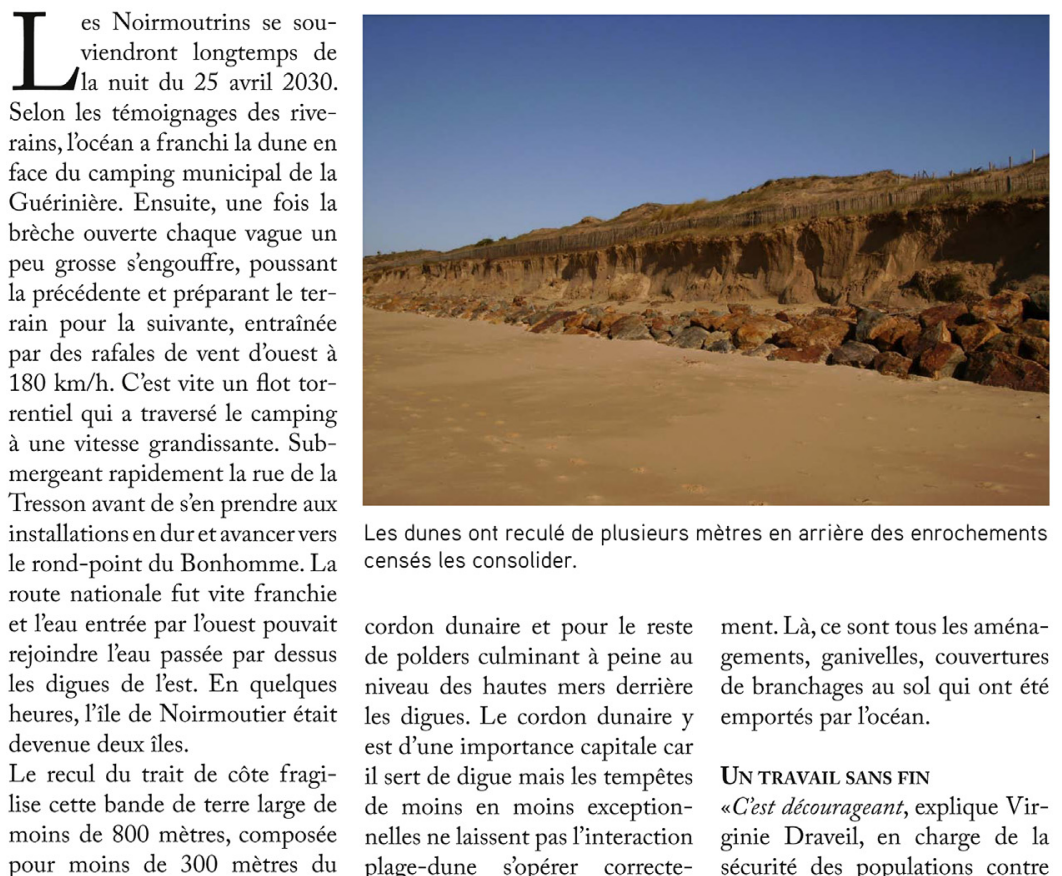

Les dunes ont reculé de plusieurs mètres en arrière des enrochements censés les consolider.

cordon dunaire et pour le reste de polders culminant à peine au niveau des hautes mers derrière les digues. Le cordon dunaire y est d'une importance capitale car il sert de digue mais les tempêtes de moins en moins exceptionnelles ne laissent pas l'interaction plage-dune s'opérer correcte-

\section{ment. Là, ce sont tous les aména- gements, ganivelles, couverture de branchages au sol qui ont été emportés par l'océan.}

\section{UN TRAVAIL SANS FIN}

"C'est décourageant, explique Virginie Draveil, en charge de la sécurité des populations contre

\begin{abstract}
la mer, en quelques heures, c'est le ner les secours, on fait état d'une travail des deux dernières années deuxième brèche dans la dune un qui a été anéanti. Régulièrement, à peu plus à l'est, aux Villages de la l'issue d'une tempête et d'une grosse Tresson. Quelques maisons sont marée, il y a des dégâts mais cette inondées et la plage a bien reculé année le bilan est lourd: l'intégra- là-bas aussi. Du côté de la plaine, lité des aménagements a disparu et, les surfaces submergées se compen plus, par endroit la dune a fait tent en dizaines d'hectares. un bond en arrière de 15 mètres. Le risque d'une séparation réPour cette saison, il va falloir tout gulière entre le nord et le sud de de même réaménager un sentier l'île de Noirmoutier devient plus piéton et limiter les passages près de crédible à chaque épisode de surla dune, dans cet état, cela peut être cote ; alors depuis le matin, l'acdangereux.»

Un passant lui objecte que c'est sur les défenses en dur qu'il aurait fallu mettre plus de moyens. Or, les ouvrages en pierre nont pas mieux résisté. Le compte-rendu des témoins des effets de la tempêtes sur les enrochements n'est pas plus réjouissant. La dune, qui ressemble plus à une falaise, est plusieurs mètres derrière les rochers. Ceux-ci disparaissent par endroit dans le sable.

A la mairie de la Guérinière, transformée en PC pour centraliser les informations et coordon-

tion est de mise. Les pelleteuses s'affairent déjà à barrer le passage à la prochaine marée haute.

A la Tresson, la dune et la digue, la pierre et le sable sont d'égale importance, ce qui oblige à ouvrir l'éventail des choix entres méthodes de protection dures et douces. Cette vision des choses prévaut à Noirmoutier, une île gagnée en grande partie sur la mer. Une île qui n'a plus beaucoup de terres à rendre ayant bien suivi son programme de dépoldérisation. La ronde infinie du réensablement n'est pas prête de s'achever.
\end{abstract}

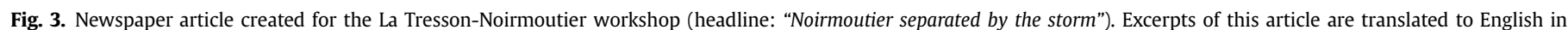
annex.

provided a common ground for discussion: whenever participants had doubts, they can come back to the 'facts'. In addition, the scenario material stimulated reactions, as the description of the storm's impacts triggered some emotional responses in the group.

With all this physical and socioeconomic data about a 2030 storm impacting their area, the group was then presented with the task of, from what they knew from their background and what they learned from the presented scenarios, advising the authorities on what actions would be the most adapted to the situation.

The role of the group facilitator was to ensure an equal participation of all stakeholders and to guarantee that the result of the group's deliberation would be correctly registered. The geoscience researchers (from BRGM, see note 2) who had created the 2030 physical scenario remained in the room to clarify any doubts about the scenario arising during the debate. However, they were not allowed to participate in the discussion and their participation was limited to answering three questions through written notes in a piece of paper. This disposition was taken so as to avoid a shift of the discussion from uncertainty and decision making into technical considerations. This risk was high since geoscientists and coast stakeholders have extensive and complementary knowledge.

This methodology is thus quite different from the approaches that are often used when stakeholders are involved. Here the matter is not so much to participate in a debate or a discussion, but to elaborate a complete set of sound data relevant to the issue at hand. The small group format strengthens interactions between participants and permits an in-depth analysis. Although developed in a research framing, it is argued that this methodology could be directly used within policy programs and actions related to coastal safety (Poumadère, 2014).

\subsection{Data analysis}

All the data from the scenario discussion was recorded, transcribed and analyzed using the content analysis program ALCESTE. The discursive material constitutes a privileged source, or via regia, for analyzing the psychosocial dynamics that are active in social representations (Kalampalikis, 2003). And considering the intrinsically dialogical nature of not only exchanges made within social groups, but in social thought in general (Billig et al., 1988), we opted for the use of the content analysis program ALCESTE - Lexical Analysis from the Context of Sets of Text Segments (Caillaud et al., 2011; Reinert, 1999). This dialogical principle is observed by this software in the way it operates successive differentiations between lexical contexts found in the corpus: it starts by opposing the two contexts with the most different vocabulary; then this operation is repeated within each of the segmented contexts, until a stable number of classes is reached (Kalampalikis and Moscovici, 2005). The main goal of the descendant hierarchical classification is to divide the sentences of the corpus into classes that contrast with each other in terms of their typical vocabulary, or semantic universes (Kalampalikis, 2003; Kalampalikis and Moscovici, 2005).

This type of analysis permits the identification of "different ways of talking, that is, the use of a specific vocabulary is seen as a source 
for detecting ways of thinking about an object" (Kronberger and Wagner, 2003, p. 307). In our case, the evaluation of these semantic universes would reveal the existence of different contents that are taken into account by stakeholders when discussing the priorities during a crisis situation in coastal regions.

\section{Results}

Results of the content analysis and of the recommendations made by the stakeholder groups in the two sites are presented below in this order: content analysis (Truc Vert and La TressonNoirmoutier) and recommendations (Truc Vert and La TressonNoirmoutier).

\subsection{Content analysis}

\subsubsection{Truc Vert}

The stakeholders that came to the Truc Vert arrived at the meeting under a storm threat: a real storm was forecasted for the day of the meeting. Civil protection and internal administration were especially cautious regarding storms those days due to the recent Xynthia storm that about a month before the workshop had caused important material damage and at least 51 fatal victims in France. For this reason, the stakeholders present in the meeting were very sensitive to the issue being discussed.

The scenario presented triggered a debate about what actions would fit best the short-term needs of those directly involved in the crisis situation. Some ideas were more consensual than other, but what was discussed can be summarized as follows: (1) informative actions by decision makers, (2) political and practical actions performed by local organizations and (3) considerations about the natural environment. The first and the second categories are closest in meaning, both opposing the content summarized by the third category (see Fig. 4 and Table 2).

\section{(1) Informative actions by decision makers}

This category refers to the exchanges made by participants about communication issues. Stakeholders started to approach the scenario situation in terms of information and communication of the situation right after the storm (usage of words related to expertise, mayor, information, among others). Opinions about who should be responsible for assessing the situation were highly consensual among participating stakeholders. On the other hand, the diffusion of this information to the local and national media was a matter that divided the group. Both sides of this debate were demonstrated by recurring to the Xynthia storm. As local

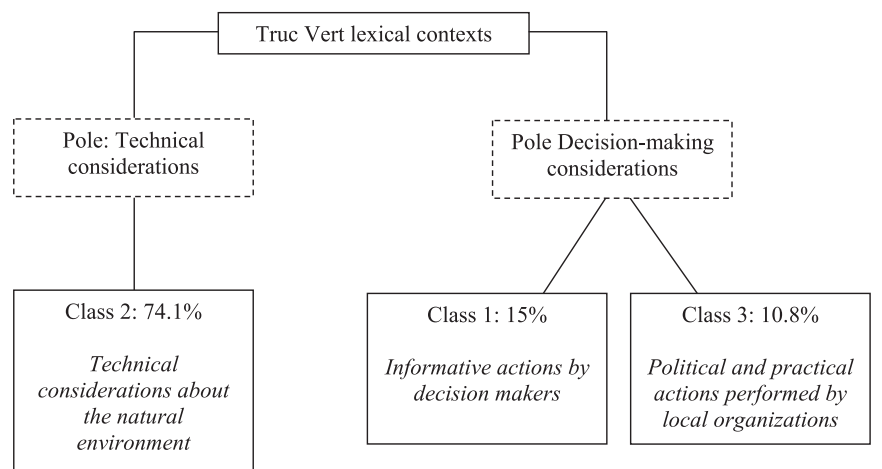

Fig. 4. Outline for the lexical classes (categories) identified in the debate between stakeholders participating in the Truc Vert workshop - ALCESTE results.
Table 2

Word contexts identified during the stakeholder workshop at Truc Vert - ALCESTE results.

\begin{tabular}{lll}
\hline Title & Most representative words & $\begin{array}{c}\text { Associated } \\
\text { variables }\end{array}$ \\
\hline $\begin{array}{l}\text { Class 1: Informative actions by } \\
\text { decision makers }\end{array}$ & $\begin{array}{l}\text { Town, information, mayor, go, } \\
\text { pass, make, Landes (local town), } \\
\text { world, appraisal, cleaning, ascend, } \\
\text { zone, effect, communication. }\end{array}$ \\
$\begin{array}{l}\text { Class 2: Technical } \\
\text { considerations about the } \\
\text { natural environment }\end{array}$ & $\begin{array}{l}\text { Dune, beach, role, zone, sand, put. } \\
\text { Class 3: Political and practical } \\
\text { actions performed by local } \\
\text { organizations }\end{array}$ & $\begin{array}{l}\text { Elected, communication, situation, Group } \\
\text { reality, Klaus (storm), association, facilitator } \\
\text { public, reaction, big, local, action. }\end{array}$ \\
\hline
\end{tabular}

inhabitants, participants had recently observed the negative effects that public communication about the storm had upon the local economy. Images of the devastated coastal areas and the media reporting on the disaster and the related fatalities contributed to a stigmatization of the region in face of the whole country. Among the consequences of this stigmatization, a direct negative impact upon regional tourism: people did not want to visit or stay in a devastated area, as they were uncertain about the state of the infrastructures by the summer vacations. Surprisingly enough, the solution for the problem was debated also as being communication. It should not be based upon sensationalist news, focusing on the storm's damage, but an informative communication, involving official positions and centered upon the reconstruction efforts made by the regional government. Words as mayor, communication, information were very frequent as part of this class.

Examples of excerpts that are part of this class:

"This is precisely were expertise is most useful, with the frame of the event, but moreover to decide what needs to be done to rehabilitate, reinstall, repair, etc"

"Who will do the expert communication? Will it be the mayor or will he transfer this responsibility to the local municipality?"

(2) Political and practical actions performed by local organizations

This category is a more punctual one given that only about $10 \%$ of the groups' exchanges included this type of content. The content of this category indicates the stakeholders' conception of the local political action. Notions used under this class describe the functioning of the local organizations: who are the people in charge, who communicates or deals with what, etc. (words associated to elected, association, situation, reaction).

It is interesting to notice that interventions made by the group facilitator were associated to this context. This is probably because his interventions often called the group discussion to more practical issues. Here are some exerts classified under this class:

"This reaction of locally elected representatives and tourism business maybe the same in 2030: we must be ready to welcome the public next summer in spite of the big storm that hit us in the winter".

"We now come back to the actions of communication. It is important. Take the local departmental council of Vendée as an example. So there are associations, the public, elected representatives".

(3) Considerations about the natural environment 
This category was the largest that emerged from discussions: $74 \%$ of the entire exchanges of the group were part of this context. For this reason, it can be considered as the content that best characterizes the exchanges of this particular group. This class includes those exchanges about technical issues involving the coastal environment (common words: dune, beach, sand). Its content is opposed to the content of the other two previous categories taken together (see Table 1).

Examples of excerpts classified as part of this context:

"If the beach is like that here after the storm, the dune on the coast of the Landes has become a cliff".

"The distance between the accreting zones and those under erosion is so large here that you cannot imagine a system alike in Capbreton, with sand transfers from the north to the south".

The concentration of the debates on this type of technical issues results not only from the nature of the proposed scenarios, but also from the roles group participants have in their daily life which make them quite knowledgeable in terms of coastal management. The predisposition of the group to consider in priority technical matters over strategic ones was counteracted by the researcher playing the role of group facilitator. His interventions appear often related to the second (and more empirically oriented) category "Actions by decision makers".

\subsubsection{La Tresson-Noirmoutier}

Local stakeholders, most of them residents of the island, were faced with the description of strong storm and its impacts upon La Tresson-Noirmoutier. One of the most striking outcomes of this storm would be the cutting of the island in half - an unprecedented but plausible event, considering the local dynamics and sediment transport over the years (see Idier et al., 2013). This striking consequence of the storm was presented on a simulation using a satellite picture of the island, and was described in the recreated newspaper article, both clearly dated in 2030 . The debate triggered by this catastrophic scenario can be summarized as follows: (1) principles and strategies of coastal risk management; (2) response to a catastrophic scenario; and (3) who's responsible? The last two categories were closest in meaning, opposing the content presented by the first category (see Fig. 5 and Table 3).

\section{(1) Principles and strategies of coastal risk management}

What distinguishes this context in relation to the other two is a more punctual account of the different possible strategies to adopt in face of possible sea level rise. The exchanges classified under this context do not show a concern with the short-term policy response,

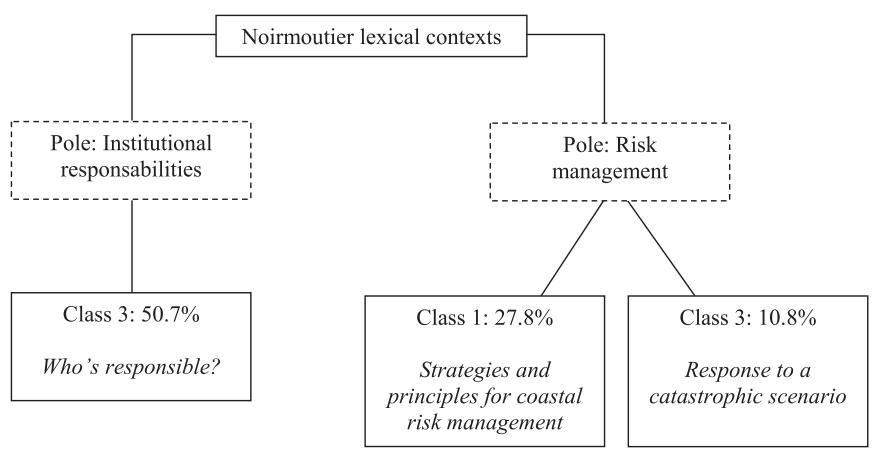

Fig. 5. Outline for the lexical classes (categories) identified in the debate between stakeholders participating in the La Tresson-Noirmoutier workshop - ALCESTE results.
Table 3

Categories identified in the stakeholder workshop at La Tresson-Noirmoutier.

\begin{tabular}{|c|c|c|}
\hline Title & Most representative words & $\begin{array}{l}\text { Associated } \\
\text { variables }\end{array}$ \\
\hline $\begin{array}{l}\text { Class 1: Strategies and } \\
\text { principles for coastal risk } \\
\text { management }\end{array}$ & $\begin{array}{l}\text { strategy, retreat, coast, littoral, zone, } \\
\text { doctrine, collectively, damage, } \\
\text { management, risk, fight, talk, } \\
\text { conscience, nature, mobile, law, } \\
\text { come }\end{array}$ & $\begin{array}{l}\text { Group } \\
\text { facilitator }\end{array}$ \\
\hline $\begin{array}{l}\text { Class 2: Response to a } \\
\text { catastrophic scenario }\end{array}$ & $\begin{array}{l}\text { water, find, done, bridge, build, } \\
\text { question, disaster, breach, pose, } \\
\text { small, response, go, evaluative, } \\
\text { scientific, event, Xynthia, type, } \\
\text { measure }\end{array}$ & \\
\hline Class 3: Who's responsible? & $\begin{array}{l}\text { elected, storm, moment, state, level, } \\
\text { local, account, value, sea, strong, } \\
\text { take, earth, preserve, charge, party, } \\
\text { true, fairly, frame, country, hear, } \\
\text { essential }\end{array}$ & Stakeholders \\
\hline
\end{tabular}

but with the long-term response and strategy. Here are some exerts classified under this category:

"The strategic retreat and relocation doctrine, which comes from the U.S., has progressively been integrated into the public policy of the coastline management".

"If we move into this perspective, what does it look like? Because the strategic relocation, someone has to manage it".

“... the 'risk zones' given back to agriculture and other primary sector use: Ok. Compare that with: building a temporary bridge to supply the north of the island, then fill-in the breach, then build a bridge that will last ...".

Here we can clearly observe that the participants cannot easily accept a strategic retreat. The rejection of this possibility seems to be anchored in the local history which they recall: their families have long fought against the sea. They experience a moral obligation to preserve what they have inherited from the previous generations. Today, together with their dry lands, they also acquired know-how about coastal protection, a knowledge that is shared by the newest generations (Table 1 ). In the words of some stakeholders, especially those coming from families that lived on the continent, it exists in this place a culture and a shared knowledge of risk that predisposes them to fight before leaving. This is precisely what this debate showed us during the workshop.

\section{(2) Response to a disaster scenario}

This category summarizes the exchanges made about the immediate response to the storm. The main difference between this category and the previous one is that this category organizes the exchanges about the immediate response, while the category discussed above summarizes exchanges about long-term strategies to tackle the risk of a marine submersion.

Once confronted with the scenario, the group of stakeholders soon decided to keep the island populated and therefore to fight against the sea. From this initial decision, other more pragmatic resolutions followed. The best example is the decision for the quick construction of a temporary bridge. The choice for the construction of a temporary construction is justified by (1) the immediate need for a connection between the northern and the southern parts of the island and, (2) by the fact that the seabed often recovers after major storms, possibly filling the gap opened by storm within a few weeks. If the gap remained opened, then the construction of a definitive bridge would be foreseen. Another solution proposed 
was the construction of a dike, instead of a bridge - filling the gap with sediment. Here are some excerpts classified under this class:

"A temporary bridge, with the help of the army, or an air bridge if necessary. Possibly, we fill in the hole, it might be possible. But if we fill it in, we must figure out if we do it as a quick fix for short term, or if we fix the things to last".

"Scientists can tell us if, between 2010 and 2030, extreme weather events became more frequent. I anticipate their answer, we can imagine it will be 'yes'. Therefore, it is an event for which we have been somewhat prepared when it occurred in 2030".

\section{(3) Who's responsible?}

Half of the group's debate was categorized as part of this category. The content of this category is complementary to that of the category (1): if in the first category long-term strategies to tackle the marine submersion threat are under discussion, in this category it is the tasks related to these strategies, along with the institutions and formal roles related to them that are under debate. The important weight of this category in relation to the other two is the result of the participants' everyday contact with these institutions and public agencies (policy people, local organizations, and government). This context demonstrates how knowledgeable this group is about the complex network of more or less specific and sometimes overlapping institutions. The attribution of tasks and their corresponding responsibilities can be better illustrated with the excerpts below:

"Basically there are two options which will lead to very different solutions in the case of Noirmoutier. Either locally elected persons continue to be in charge of sea protection, or this role is given to the central State, as we've just discussed".

"I think there is as well a need for a very strong will at the local level, in such a way that the State, above, will feel the need to do something, or else it will do nothing".

Also worth noticing is that these passages were associated exclusively with the stakeholders participating in the discussion, i.e., they were not associated with the group facilitator. It is also possible that through this type of content, stakeholders are negotiating and re-stating their own roles and responsibilities in face of a foreseen extreme event.

\subsection{Recommendations}

\subsubsection{Truc Vert}

During their debate, Truc Vert stakeholders organized their main recommendations on a whiteboard in simple statements that appeared to be consensual among all members. Their resolutions were:

\section{0 . Prerequisites (Crisis center). Inventory.}

1. Preservation of the protective role of the dune: financing actions

a. Avoid heavy works on the dune (remodeling or bulldozer e.g.)

b. Protection covering and re-vegetal0069zation: crossed financing

c. Conservation of the tide-mark, with a manual collection of waste

2. Site rehabilitation: town support for the touristic season

a. Safety issues (falling trees, parking, etc.)

b. Planning tourism reception service

3. Communication a. Two aspects: communication problem and stigmatization effect (affected area less attractive for tourism)

b. Responsible: mayor

c. External communication: Which administrative level, local town or departmental council?

The session was then concluded by comments by the geoscience specialists present. They stated their surprise with the fact that, despite being the main goal of the whole project, the subject of climate change was virtually absent from the debate. The whole group discussed this as a matter of level of policymaking, where local actions to reduce coastal vulnerability to storms and marine erosion are often disconnected from more centralized strategies for climate change adaptation.

\subsubsection{La Tresson-Noirmoutier}

During their debate, the group elected a voluntary that would take notes on a whiteboard about their main decisions. As we have seen above and similarly to what was observed in the Truc Vert workshop, the discussion turned around the need to tackle the damages caused by the storm in a short-term frame. The stakeholders participating in the group agreed to take the following actions:

1. Crisis management: with the help of the army, a provisional bridge could be built to connect the two halves of the island, "to let the people from the north pass, before filling the gap".

2. Managing the situation, because "letting nature take its course would be economically mortal to the island". In this sense, participants agreed that the areas in risk of inundation would be exclusively used for farming and leisure activities. On the other side, the areas off risk would be more densely inhabited (more collective buildings, or even towers).

It was particularly difficult for this group to be faced with the bad news of the storm's impacts. These affective responses were identified especially when the satellite map showing the island cut in two parts after the 2030 storm was projected - the group remained quiet for a while. This emotional response was especially strong for those participants dwelling in the Noirmoutier Island. After a recovery period, the discussion started slowly.

Despite this emotional response from representatives of generations of insular inhabitants who have fought for their territory (Noirmoutier is polderised in many areas, see Table 1), participants considered the scenario of their island cut in half to be a plausible storm outcome, which they regarded very seriously. They also underlined that the workshop format made it possible for them to discuss and seriously consider a very delicate and difficult issue. While they are well aware that this type of risks is foreseeable in a not too distant future, they normally avoid discussing it. Among these avoidance strategies, they mentioned that they easily engage into interpersonal conflicts as a way to block decision and action. From a deontological point of view, researchers ought to be aware of participants' sensitivity when exposing them to the 'bad news' of a scenario, showing caution and care when dealing with information that might be unsolicited at some levels (Poumadère et al., 2010).

\section{Discussion}

In this study, stakeholders from two different sandy beaches of the French Atlantic coast were exposed to the scenario of a storm taking place in 2030, and were required to advise policymakers based on their local knowledge of the region. The two regions elected for the study had very different socio-economic 
characteristics that would ultimately engender distinct courses of debate and advice by the stakeholders groups. In this paper we have been especially interested in the content of what has been brought to discussion during this scenario workshop exercise; and in the resolutions they privileged when asked to give policymakers advice about the required decisions.

In general, discussions during the two workshops drifted along technical and pragmatic subjects, which are closer to the participants' daily activities. This was especially the case at the Truc Vert (Aquitaine) workshop, where the most pragmatic and decisionoriented points were associated to the group facilitator. This disposition may suggest that the task at hand, i.e. to debate concrete decisions, did not occur spontaneously and the group facilitator had to remind in different occasions what the task of the group really was. Other topics discussed by the group include informative actions performed by decision makers, among other technical exchanges about the region's coastal environment. Globally, the Truc Vert stakeholders group was more concerned with practical matters about the local, short-term management of the situation presented. The proposed scenario did not encourage them to discuss long-term strategies that could prevent the event from happening, as it was observed in the La Tresson-Noirmoutier group.

This apprehension of possible future consequences suggests that the La Tresson-Noirmoutier group felt concerned by the task to the point of projecting themselves into the future. In contrast to what was observed at the Truc Vert group, the La TressonNoirmoutier group did not discuss short-term communication strategies in order to limit the possible stigmatization of the island as a tourist destination - the island's population shifts from 10,000 to 80,000 in the summer period. Participants in the La TressonNoirmoutier group also discussed technical details, but not to the same extent as did the Truc Vert group. At La Tresson-Noirmoutier, topics related with technical issues account for $23.4 \%$ of the discussions of the group, while at the Truc Vert workshop this percentage rises to $74.1 \%$. Stakeholders at La Tresson-Noirmoutier oriented their debate toward institutional responsibilities - "who is responsible for what?" - and on principles and strategies for coastal risk management.

Moreover, stakeholders groups used different approaches to propose a response to the storm. In La Tresson-Noirmoutier for example, participants were able to use both a rational and a more emotionally based appraisal of the marine submersion risk. Participants considered immediate action as well as longer-term decisions in response, and discussed the responsibility of the different institutions that would be involved. In the Truc Vert group, discussions were focused upon rational solutions: repairing the storm's damage, and planning a communication strategy that would be at the same time informative and avoidant of the negative effect that storm damage could have on the image of the region as a vacation destination.

Basic contextual characteristics could explain these differences in the approach stakeholders favored to the storm situation. The Truc Vert beach is a beach free of dwellings, thus with no significant human issue. On the other hand, Noirmoutier, is a partly polderised, inhabited island, where over generations people have worked hard to gain land from the sea. This battle of the islanders against the sea has probably contributed to shape the local identity as partly based upon the distinction between the island's residents and those from the continent.

Besides the cultural and identity bounds shared by local inhabitants, the stakeholders groups were also particularly influenced by scientific input. Several of the participants had themselves a scientific training and are, as we can observe by the content of the debates, active disseminators of scientific knowledge relating to their local context. The option of the team for opening the possibility of information exchange between the participating stakeholders and the geoscientists - even if only indirectly through written questions - satisfied the groups' need for technical support, and favored the orientation of their debate towards consensual decision-making. Without this option, it is possible that the groups would have based their discussion in overly technical issues, and maybe engage in interpersonal controversy. Despite the importance of knowing the scientific facts, decision-making under uncertainty requires skills that transcend the present situation. They involve strategic reasoning associated with a deep understanding of the territory, its numerous stakes, and its past history, along with the capacity to manage interpersonal interactions.

To summarize, these results suggest that recommendations made by each of the stakeholder groups were framed according to each region's socio-economic needs and priorities. In the Truc Vert, an area with very few economical activities and with a seasonal occupation, the group decided to let the nature take its course, focusing their efforts at the communication level to reassure potential tourists. Nothing was foreseen in terms of either withdrawal or defense, therefore characterizing a 'wait and see' position (see also Poumadère et al., 2008; Tol et al., 2006).

In La Tresson-Noirmoutier however, a defensive position was favored at all times. These participants were particularly concerned with the future of the island and were ready to recommend that all the necessary measures to defend their territory should be taken. As one of the stakeholders, who had recently moved in the island, mentioned in the interview before the workshop: "I feel that the islanders are deeply attached to their land and ready to fight against the sea. It is part of their culture. We can say they have a risk culture". The more cultural bounds and representations are implicit to inhabitants, the more powerful they are (Billig et al., 1988). Similar results were found by Baggio and Rouquette (2006) with populations living in areas exposed to the risk of flooding.

Considering the above mentioned elements and the fact that public policy is often confronted to the problem of integrating stakeholders' point of view, the methodological developments here presented provide useful tools for the implementation of risk governance research, especially for populated coastal regions. The scenario development and the stakeholder's workshop methodology were the outcome of an interdisciplinary approach only possible with the close cooperation between geoscientists and social scientists. Together, these different disciplines were able to propose a vulnerability model for these regions that combines the physical, the socio-economic and the policy dimensions.

\section{Acknowledgments}

This work was supported by the French Agence Nationale de la Recherche (ANR), through the VMC program under Grant number ANR VMC06-009, and coordinated by the French Bureau de Recherches Géologiques et Minières (BRGM).The authors thank all the research partners and the participants to the stakeholders scenario workshops. The content presented here is the sole responsibility of the authors.

\section{Appendix A. Supplementary data}

Supplementary data related to this article can be found at http:// dx.doi.org/10.1016/j.ocecoaman.2014.12.024.

\section{Annexes}

Translation of excerpts of the article presented on Fig. 2 (Truc Vert): 
The ocean has broken the dune cordon

The storm on March 26, 2030 will long remain memorized in the minds of the Bassin d'Arcachon inhabitants. From the locals' memory, never before had the ocean gone over the Truc Vert dune. The result is an appalling and questioning spectacle which overall nourishes the heated discussion between the locals and the numerous experts who came to assess the damage. One question only stands: and now, what should we do?

The news about the "disaster" attracts since Saturday the locals, elected bodies, employees from the National Forests Agency and from the National Coastal Agency. The foot of the dune resembles an open sky forum. Topic of the day: the short-term future of the beach and the actions to undertake immediately (...). For sure, this extreme event will certainly require the use of new types of action, the invention or adaptation of solutions coming from comparable experiences in similar coastal zones.

Translation of excerpts of the article presented on Fig. 3 (La Tresson-Noirmoutier):

\section{Noirmoutier separated by the storm}

The storm Victor badly hit the Noirmoutier Island which was cut in two parts when the ocean went over the dune at La Tresson. First report on location.

Noirmoutier inhabitants will remember for a long time the night of April 25, 2030. According to residents, the ocean went over the dune at the level of the camping site at La Guérinière. Then, once this breach opened, each big wave gets in, pushing the previous one and preparing the way for the next one, pulled along by West wind gusts of $180 \mathrm{~km} / \mathrm{h}$. It is a torrential flood which went through the camping site at an increasing speed (...). Quickly the main road was flooded and the water which entered on the West side could join the water that went over the Eastern dikes. In a few hours, the Noirmoutier Island had become two islands.

\section{References}

Adger, W.N., Hughes, T.P., Folke, C., Carpenter, S.R., Rockström, J., 2005. Socialecological resilience to coastal disasters. Science 309, 1036-1039.

Baggio, S., Rouquette, M.L., 2006, La représentation sociale de l'inondation: influence croisée de la proximité au risque et de l'importance de l'enjeu. Bull. Psychol. 59, 103-117.

Billig, M., Condor, S., Edwards, D., Gane, M., Middleton, D., Radley, A., 1988. Ideological Dilemmas: a Social Psychology of Everyday Thinking. Sage, London.

Burck, J., Marten, F., Bals, C., 2013. The Climate Change Performance Index Results 2014. Available at: www.germanwatch.org/en/ccpi (accessed on 03.09.14.)

Caillaud, S., Kalampalikis, N., Flick, U., 2011. The social representations of the Bali climate conference in the French and German Media. J. Community \& Appl. Soc. Psychol. 22, 363-378.

Castro, P., 2002. Notas para uma leitura da teoria das representações sociais em S. Moscovici. Análise Soc. 37, 949-979.

Castro, P., Lima, M.L., 2001. Old and new ideas about the environment and science: an exploratory study. Environ. Behav. 33, 400-423.

CLIMATE-ADAPT, 2014. European Climate Adaptation Platform. Available at: http:// climate-adapt.eea.europa.eu/ (accessed on 25.08.14.).

Delicado, A., Schmidt, L., Guerreiro, S., Gomes, C., 2012. Pescadores, conhecimento local e mudanças costeiras no litoral Português. Rev. Gestão Costeira Integr. 12 (4), 437-451.

Dupuy, J.-P., 2004. Pour Un Catastrophisme Éclairé. Seuil, Paris.

Gruev-Vintila, A., Rouquette, M., 2007. Social thinking about collective risk: how do risk related practice and personal involvement impact its social representations? J. Risk Res. 10, 555-581.

Idier, D., Castelle, B., Poumadère, M., Balouin, Y., Bertoldo, R., Bouchette, F., et al.Vinchon, C., 2013. Vulnerability of sandy coasts to climate variability. Clim. Res. 57 (1), 19-44.

IPCC, 2007. Summary for policymakers. In: Solomon, S., Qin, D., Manning, M. Chen, Z., Marquis, M., Averyt, K.B., Tignor, M., Miller, H.L. (Eds.), Climate Change 2007: the Physical Science Basis. Contribution of Working Group I to the Fourth Assessment Report of the Intergovernmental Panel on Climate Change. Cambridge University Press, Cambridge, United Kingdom and New York, NY, USA.

IPCC, 2014. Summary for policymakers. In: Field, C.B., Barros, V.R., Dokken, D.J., Mach, K.J., Mastrandrea, M.D., Bilir, T.E., Chatterjee, M., Ebi, K.L., Estrada, Y.O. Genova, R.C., Girma, B., Kissel, E.S., Levy, A.N., MacCracken, S., Mastrandrea, P.R. White, L.L. (Eds.), Climate Change 2014: Impacts, Adaptation, and Vulnerability. Contribution of Working Group II to the Fifth Assessment Report of the Intergovernmental Panel on Climate Change. Cambridge University Press, Cambridge, United Kingdom and New York, NY, USA, pp, 1-32.

Joffe, H., 2003. Risk: from perception to social representation. Br. J. Soc. Psychol. 42 $55-73$.

Kalampalikis, N., 2003. L'approche de la méthode Alceste dans l'analyse des représentations sociales. In: Abric, J.-C. (Ed.), Méthodes d'études des représentations sociales. Editions Erès, Paris, pp. 147-163.

Kalampalikis, N., Moscovici, S., 2005. Une approche pragmatique de l'analyse Alceste. Cah. Int. Psychol. Soc. 66, 15-24.

Knorr-Cetina, K., 1997. Sociality with objects: social relations in postsocial knowledge societies. Theory, Cult. Soc. 14, 1-30.

Kronberger, N., Wagner, W., 2003. Keywords in context: statistical analysis of text features. In: Bauer, M., Gaskell, G. (Eds.), Qualitative Researching with Text Image and Sound. A Practical Handbook. Sage Publications, London, pp. 299-317.

Lamson, C., 2008. Planning for resilient coastal communities: lessons from ecological systems theory. Coast. Zone Manag. J. 13, 265-280.

Lévi-Bruhl, L., 1910/1985. How Natives Think. Princeton University Press, Princeton.

Meinshausen, M., Meinshausen, N., Hare, W., Raper, S.C.B., Frieler, K., Knutti, R. Allen, M.R., 2009. Greenhouse-gas emission targets for limiting global warming to 2 degrees C. Nature 458 (7242), 1158-1162.

Moscovici, S., 2008. Psychoanalysis: its Image and its Public. Polity Press Cambridge.

Olivier, J.G.J., Janssens-Maenhout, G., Muntean, M., Peters, J.A.H.W., 2013. Trends in Global CO2 Emissions: Report 2013. PBL Netherlands Environmental Assessment Agency, The Hague.

Poumadère, M., 2014. Storm on the French Atlantic Coast: scenario and stakeholder reasoning. In: Presentation at the Risk Policy Conference: Explicitly Dealing with Safety: Learning from Excellence in Europe, Organized by the Netherlands Ministry of Infrastructure and the Environment, Scheveningen, April 22-23, 2014.

Poumadère, M., Mays, C., Pfeifle, G., Vafeidis, A.T., 2008. Worst case scenario as stakeholder decision support: a 5- to 6-m sea level rise in the Rhone delta, France. Clim. Change 91, 123-143.

Poumadère, M., Bertoldo, R., Samadi, J., 2011. Public perceptions and governance of controversial technologies to tackle climate change: nuclear power, carbon capture and storage, wind, and geoengineering. Wiley Interdiscip. Rev. Clim. Change 2, 712-727.

Poumadère, M., Bertoldo, R.B., Balouin, Y., Idier, D., Mallet, C., Robin, M., Ruz, M.H., Oliveros, C., 2010. Gouvernance des risques climatiques et vulnérabilité du littoral:Méthodologie du scénario 2030, de l'atelier de parties prenantes et des représentations sociales. Impacts du changement climatique sur les risques côtiers, Journées "Impacts du Changement Climatique sur les Risques Côtiers". BRGM, France. Available at: www.brgm.fr/sites/default/files/risques_cotiers 2010_actes.pdf\#page $=126$.

Reinert, M., 1999. Quelques interrogations à propos d'une analyse de discours de type statistique et de la réponse Alceste. Langage Société 90, 57-70.

Renn, O., 2008. Risk Governance: Coping with Uncertainty in a Complex World Earthscan, London.

Tol, R.S.J., Bohn, M., Downing, T.E., Guillerminet, M., Hizsnyik, E., Kasperson, R., Lonsdale, K., et al., 2006. Adaptation to five metres of sea level rise. J. Risk Res. 9, 467-482.

UNEP, 2007. Coastal Population and Altered Land Cover in Coastal Zones (100 Km of Coastline). UNEP/GRID-Arendal Maps and Graphics Library. Available at: http:// maps.grida.no/go/graphic/coastal-population-and-altered-land-cover-incoastal-zones-100-km-of-coastline (accessed on 03.09.14.).

Uzelgun, M.A., Castro, P., 2014. Voice of science on climate change in the mainstream Turkish press. Environ. Commun. 8, 326-344. 